\title{
ASSESSMENT OF DIETARY SUPPLEMENTATION OF TURMERIC (CURCUMA LONGA) AS A PHYTOBIOTIC ON BROILER PERFORMANCE AND BACTERIAL COUNT
}

\author{
Inas Ahmed"; T. El-Rayes ${ }^{2}$ and AlShaymaa I. Ahmed ${ }^{3}$ \\ 1. Anim. and Poult. Prod. Dept., Faculty of Agric. and Natural Resources, Aswan Univ., Egypt. \\ 2. Animal Prod. Dept., Faculty of Agric., Tanta Univ., Egypt. \\ 3. Agricultural Microbiology Dept., Faculty of Agric., and Natural Resources Aswan Univ., Egypt.
}

(Received 25/6/2018, accepted 8/8 /2018)

SUMMARY

$\mathrm{T}$

The current experiment was carried out to evaluate the impact of different levels of turmeric (Curcuma longa) as a phytobiotic on the performance and bacterial count of broiler chickens. A total of 240 unsexed day old Cobb chicks were allocated randomly to four dietary treatments each with three replicates of 20 chicks/replicate. Four experimental diets included (T1) a basal diet without turmeric addition (control), (T2) a basal diet with $0.25 \%$ turmeric, (T3) a basal diet with $0.5 \%$ turmeric and (T4) basal diet with $1 \%$ turmeric. The feeding trail was conducted for 42 days. Body weight, weight gain, some carcass characteristics, and bacterial count were recorded. Feed intake and feed conversion ratio were calculated. Results showed that final body weight and weight gain were significantly $(\mathrm{P}<0.05)$ increased in birds fed diet supplemented with different levels of turmeric powder as compared to the control group. Birds fed diet supplemented with 0.25 or $0.5 \%$ turmeric powder recorded significantly $(\mathrm{P}<0.05)$ improvement in feed conversion ratio, carcass, heart, thymus and spleen percentages as compared to the control group. On the other hand, there were significant $(\mathrm{P}<0.05)$ decreases in liver, gizzard and total giblets percentages of birds supplemented with dietary turmeric powder at all levels as compared to the control group. No significant $(\mathrm{P}>0.05)$ differences were detected in feed consumption, dressing and bursa of fabricius percentages between dietary treatments. Total bacterial count was significantly $(\mathrm{P}<0.05)$ lowest for all supplemented groups as compared to the control. Whereas, coliform group, fecal E. coli, Staphylococcus aureus, Salmonella sp., Shigella sp., and Listeria sp. count were significantly $(\mathrm{P}<0.05)$ decreased for all supplemented groups as compared to the control. Total lactic acid bacteria count was significantly $(\mathrm{P}<0.05)$ increased for all supplemented groups as compared to the control. It could be concluded that, adding turmeric powder supplementation to broiler diet as a growth promoter, at level of $5 \mathrm{~g} / \mathrm{kg}$ diet recorded superior effects on their productive performance and bacterial count.

Keywords: Turmeric, broiler, performance, bacterial count.

\section{INTRODUCTION}

For many years, a variety of synthetic feed additives such as drugs and antibiotics were used as growth promoters in livestock and poultry nutrition to improve the efficiency of production, product quality, modify the gut microflora and to control diseases in broiler chickens (Bedford, 2000 and Whitehead, 2002).

Antimicrobial agents usually associated with adverse effects on the host like, development of antibiotic-resistant bacteria (Barton 1998). Due to these concern, in the modern era and over the several last years, much researches around the world had been focused on the development of alternative strategies to maintain poultry health and enhance performance within intensive systems, and numerous substances, commonly known as natural growth promoters (NGPs) have been identified as effective alternatives to antibiotics (Farag and El-Rayes, 2016). Also, many researchers have evaluated an effective antimicrobial compounds from alternative and natural sources like plants and herbs, which 


\begin{abstract}
Ahmed et al.
benefits the health of digestive tract (Patterson and Burkholder, 2003; Stephen and Hargreaves, 2007 and Al-Mashhadani, 2015).

Phytobiotics represent a wide range of bioactive compounds that can be extracted from various plant sources. Many medicinal plants can be used as potential phytobiotic compounds to improve productive performance and modify the gut microflora in broiler chickens. (Bedford, 2000 and Wenk, 2003). Bioactive phytobiotic compounds led to beneficial effects in animal nutrition, it may be due to the stimulation of feed consumption, improving the secretion of endogenous digestive enzyme, enhancing of immune response and antimicrobial and antioxidant actions (Toghyani et al., 2010, 2011).

Turmeric (Curcuma longa) is one of herbaceous plant that belongs to the Zingiberaeceae family. It has a wide range of bioactive compounds that can be extracted from it such: curcumin, dimethoxycurcumin, bisdomethoxycurcumin, (Wuthi-Udomlert et al., 2000) and tetrahydrocurcuminoids (Osawa et al., 1995). So, it has antimicrobial, antioxidant and other useful properties. Also, it has been used in the old ages as a flavoring agent, a medicinal herb, and a dyeing agent (Iqbal et al., 2003 and Chaturvedi, 2009). Moreover, Curcumin has been studied as an anti-inflammatory (Holt et al., 2005), a chemo preventive agent (Duvoix et al., 2005). It is used in gastrointestinal and respiratory disorders (Anwarul et al., 2006). In addition, Soni et al., (1997) reported the protective effects of turmeric in the prevention of aflatoxin-induced mutagenicity and hepatocarcinogenicity.

Many researchers evaluated the effects of dietary turmeric supplementation on broiler performance. Also, Various studies have shown the antimicrobial effects of extracts of roots of Curcuma longa on various microorganisms like Staphylococcus aureus, Staphylococcus epidermidis, Enterococcus faecalis, Escherichia coli, Klebsiella pneumonia, Candida albicans, and Candida kruseii (Rambir et al., 2002; Niamsa and Sittiwet, 2009; Kang-Ju Kim et al., 2005 and Park et al., 2005); however, the results have not been consistent. The current study was conducted to shed more light on the effect of different levels of turmeric powder as feed additive on productive performance, carcass characteristics and intestinal microflora of broiler chick.
\end{abstract}

\title{
MATERIALS AND METHODS
}

This experiment was carried out at a private commercial poultry farm under supervision of Animal Production Department, Faculty of Agriculture, Tanta University.

\section{Birds and management:}

A total number of 240 unsexed one-day-old Cobb broiler chicks were individually weighed and randomly distributed into four equal groups, each included three replicates of 20 chicks. Four experimental diets included (T1) a basal diet without turmeric addition (control), (T2) a basal diet with turmeric at the level of $0.25 \%$, (T3) a basal diet with turmeric at the level of $0.5 \%$, (T4) a basal diet with turmeric at the level of $1 \%$. The experimental diets were formulated to cover all nutrient requirements of broiler chicks according to (NRC, 1994). The composition and calculated analysis of the basal diet are presented in Table 1. The response of the chicks was assessed in terms of weekly body weight, weight gain, feed intake and feed conversion ratio. At 42 days of age, three birds from each treatment were sacrificed, scalded, de-feathered and carcasses were eviscerated and evaluated.

\section{Bacterial enumeration:}

Ten grams of the ileal digesta were weighed in a sterile stomacher bag, and then $90 \mathrm{ml}$ from maximum recovery diluents was added to the sample, the sample was well mixed using stomacher machine. Further serial dilution was done (if needed) by a mean of a $1 \mathrm{ml}$ pipette transferred into two petri dishes, and then the media were poured.

Appropriate dilutions prepared from ileal digesta sample were used for inoculating different nutrient and selective media. The bacteriological examinations of ileal digesta samples included total bacterial counts, total coliform, fecal coliform, Salmonella spp., total lactic acid bacteria and Shigella spp, total listeria sp. and total staphylococcus ssp. The identification and enumeration procedures were carried out in the Department of Microbiology, Faculty of Agriculture, Ain Shams University, as described below. 
Table (1): Composition and calculated analyses of the experimental diets

\begin{tabular}{|c|c|c|}
\hline Ingredients & Starter & Finisher \\
\hline Yellow corn & 50.48 & 63.60 \\
\hline Soybean meal (44\%) & 32.65 & 26.90 \\
\hline Corn gluten meal $(62 \%)$ & 7.00 & 1.23 \\
\hline Vegetable Oil & 6.00 & 4.86 \\
\hline Ground limestone & 1.45 & 1.20 \\
\hline DI-Calcium Phosphate & 1.69 & 1.41 \\
\hline $\mathrm{NaCl}$ & 0.30 & 0.30 \\
\hline Permix* & 0.30 & 0.30 \\
\hline DL-methionine & 0.10 & 0.10 \\
\hline L-Lysine $\mathrm{HCl}$ & 0.03 & 0.10 \\
\hline Total & 100 & 100 \\
\hline \multicolumn{3}{|l|}{ Calculated analysis** } \\
\hline Crud protein, $\%$ & 23.00 & 18.03 \\
\hline Metabolizable energy (K cal/kg) & 3200 & 3200 \\
\hline Ether extract (EE \%). & 2.40 & 2.66 \\
\hline Crude fiber $(\mathrm{CF} \%)$ & 3.50 & 3.30 \\
\hline Calcium & 1.03 & 0.86 \\
\hline Available phosphorus, $\%$ & 0.45 & 0.39 \\
\hline Lysine, $\%$ & 1.11 & 0.90 \\
\hline Methionine & 0.50 & 0.40 \\
\hline
\end{tabular}

\section{Counts of total bacteria:}

Enumeration of total plate count was carried out according to ISO 4833 (2003). Ten-fold serial dilution of the bacterial suspension was made. This was done until $10^{-7}$ dilution was achieved. Then 0.1 $\mathrm{ml}$ was pipetted from the $10^{-7}$ dilution onto the surface of each of two Petri dishes containing $15 \mathrm{ml}$ of a solidified and sterile plate count agar (PCA), and then spread evenly with a sterile glass spreader. The plates were then incubated for a maximum of $24-72 \mathrm{hrs}$. at $30^{\circ} \mathrm{C}$ (including the control plates).

\section{Counts of total lactic acid bacteria:}

Total lactic acid bacteria were enumerated on MRS Agar (Difco) by serial dilutions $\left(10^{-5}\right.$ and $\left.10^{-7}\right)$. Plates were incubated in an aerobic condition by using pouring plate technique at $37^{\circ} \mathrm{C}$ for $24-72$ hours.

\section{Counts of total coliforms and faecal coliform:}

Total coliforms and fecal coliform were estimated on a MaConkey agar (Eaton et al., 1995) using pouring plate technique by serial dilution $\left(10^{-3}\right.$ and $\left.10^{-4}\right)$. Plates were incubated aerobically at $37^{\circ} \mathrm{C}$ for total coliforms or $44.5^{\circ} \mathrm{C}$ for fecal coliform for 24-48 hours for coliform and fecal coliform, respectively.

\section{Counts of Salmonella spp:}

Detection of salmonella was carried out according to modified ISO 6579 (2002). Twenty-five grams of the ileal sample were weighed in a sterile stomacher bag or flask, and then $225 \mathrm{ml}$ of buffer peptone water was added, then $1 \mathrm{ml}$ was plated onto XLD plates and incubated at $37{ }^{\circ} \mathrm{C}$ for $24-48 \mathrm{hrs}$. Typical colonies of Salmonella in XLD were red with black centre. Biochemical reaction (triple sugar iron agar, lysine iron agar, citrate agar and urea agar) was used for confirmation of Salmonella typical colonies.

Data were subjected to the analysis of variance by using the General Linear Models (GLM) Procedure of the Statistical Analysis System (SPSS, version, 18.0; 2010), according to the following model: $Y_{i j}=\mu+T_{i}+e_{i j}$. Where: $Y_{i j}=$ observation. $\mu=$ overall mean. $T_{i}=$ a fixed effect of treatment. $\mathrm{e}_{\mathrm{ijk}}=$ experimental error.

Differences among treatment means were detected using Duncan's multiple range test (Duncan, 1955). 


\section{RESULTS AND DISCUSSION}

Data presented in Tables (2 and 3) showed the influence of turmeric supplementation at different levels $(0,0.25,0.5$, and $1 \%)$ on productive performance of broiler chicks during all experimental periods. Data revealed that, live body weight values at 21 days of age were not affected $(p>0.05)$ by turmeric supplementation levels. Hence, at 42 days of age, birds fed dietary $0.5 \%$ turmeric recorded significantly $(\mathrm{P} \leq 0.05)$ increased in body weight by $7.77 \%$ compared to control. During the starter period, weight gain was not influenced $(\mathrm{P}>0.05)$ by turmeric supplementation at all levels. Even though, weight gain of broiler chicks fed dietary $0.5 \%$ dietary turmeric significantly $(\mathrm{P} \leq 0.5)$ increased by 7.89 and $7.89 \%$ as compared to the control group during finisher and the entire experimental period, respectively.

Table (2): Average body weight of broiler chicks as affected by turmeric supplementation levels.

\begin{tabular}{lccc}
\hline Turmeric levels \% & Initial BW $(\mathrm{g})$ & BW at 21 day $(\mathrm{g})$ & Final BW at 42 day $(\mathrm{g})$ \\
\hline Control (T1) & 41.7 & 796.5 & $2373.8^{\mathrm{b}}$ \\
$0.25 \%(\mathrm{~T} 2)$ & 42.1 & 828.5 & $2470.3^{\mathrm{ab}}$ \\
$0.50 \%$ (T3) & 42.2 & 837.3 & $2558.2^{\mathrm{a}}$ \\
$1.00 \%(\mathrm{~T} 4)$ & 41.9 & 804.5 & $2431.2^{\mathrm{ab}}$ \\
$\mathrm{SEM}$ & \pm 0.6 & \pm 14.24 & \pm 51.07 \\
Significant & $\mathrm{NS}$ & $\mathrm{NS}$ \\
\hline \multicolumn{2}{l}{ a and $\boldsymbol{b}:$ Means of each column followed by the same letter are not significantly different at the 5\% level according } \\
to Duncan's Multiple Range Test. & SEM indicate standard error of means \\
NS indicate not significant. & $*$ indicate P<0.05
\end{tabular}

Table (3): Average body weight gains (BG), feed consumption (FC), feed conversion ratio (FCR) of broiler chicks as affected by turmeric supplementation levels.

\begin{tabular}{|c|c|c|c|c|c|c|c|c|c|}
\hline \multirow{2}{*}{$\begin{array}{l}\text { Turmeric } \\
\text { levels } \%\end{array}$} & \multicolumn{3}{|c|}{$\begin{array}{c}\text { Starter Period } \\
\text { From } 0-21 \text { days of age }\end{array}$} & \multicolumn{3}{|c|}{$\begin{array}{c}\text { Finisher Period } \\
\text { From } 21-42 \text { days of age }\end{array}$} & \multicolumn{3}{|c|}{$\begin{array}{c}\text { Total Period } \\
\text { From } 0-42 \text { days of age }\end{array}$} \\
\hline & WG & $\mathrm{FC}$ & FCR & WG & $\mathrm{FC}$ & FCR & WG & $\mathrm{FC}$ & FCR \\
\hline Control (T1) & 754.8 & 1024.5 & 1.36 & $1577.3^{b}$ & 3602 & $2.28^{\mathrm{a}}$ & $2332.1^{b}$ & 4626.5 & $1.98^{\mathrm{a}}$ \\
\hline $0.25 \%(\mathrm{~T} 2)$ & 786.4 & 1042 & 1.33 & $1641.8^{\mathrm{ab}}$ & 3549.5 & $2.16^{\mathrm{ab}}$ & $2428.2^{\mathrm{ab}}$ & 4591.5 & $1.89^{\mathrm{ab}}$ \\
\hline $0.50 \%$ (T3) & 795.1 & 1045.5 & 1.31 & $1720.9^{\mathrm{a}}$ & 3620.5 & $2.10^{\mathrm{b}}$ & $2516^{\mathrm{a}}$ & 4617 & $1.83^{\mathrm{b}}$ \\
\hline $1.00 \%(\mathrm{~T} 4)$ & 762.6 & 1023 & 1.34 & $1626.7^{\mathrm{ab}}$ & 3523.5 & $2.17^{\mathrm{ab}}$ & $2389.3^{\mathrm{ab}}$ & 4546.5 & $1.90^{\mathrm{ab}}$ \\
\hline SEM & \pm 43.6 & \pm 5.25 & \pm 0.02 & $62.7 \pm$ & \pm 34.25 & \pm 0.13 & $67.4 \pm$ & \pm 26.87 & \pm 0.07 \\
\hline Significant & NS & NS & NS & $*$ & NS & $*$ & $*$ & NS & $*$ \\
\hline
\end{tabular}

Adding turmeric to broiler chick diet did not significantly $(\mathrm{P}>0.05)$ affect on feed consumption during all experimental periods. Also, feed conversion ratio was not influenced $(\mathrm{P}>0.05)$ by turmeric additions during the starter period. On the other hand, FCR of broiler chicks fed $0.5 \%$ dietary turmeric significantly $(\mathrm{P} \leq 0.5)$ improved by 9.1 and $7.57 \%$ as compared to the control group during finisher and the entire experimental period, respectively. The significant improvement in productive performance of birds fed diet supplemented with $5.0 \mathrm{~g} / \mathrm{kg}$ turmeric powder may be due to the ideal antioxidant activity which stimulates the synthesis of proteins from the bird's enzyme system. Also, it was stated that, turmeric would be possible to promote digestive enzyme and pancreatic lipase (Platel and Srinivasan, 2000). Additionally, Rajput et al., (2012) cited that the inclusion of pure curcumin at level of $0.2 \%$ improved length and weight of the duodenum, jejunum and ceca villus of growing broiler chick. Moreover, turmeric could modify the gut microflora in broiler chickens resulting in balanced gut microbial ecosystem that leads to improvement of feed utilization represented in body weight and weight gain. The previous results are in agreement with findings of (Al-Sultan, 2003 and Durrani et al., 2006) who reported that turmeric meal supplementation at the rate of $0.5 \%$ improved growth performance of broiler chicken at 42 days of age. In addition, these results are compatible with those reported by $\mathrm{Al}$ - 
Mashhadani, (2015), who found that final body weight and weight gain increased by increasing supplementation level of turmeric up to $4.0 \mathrm{~g} / \mathrm{kg}$.

The impact of turmeric supplementation levels $(0,0.25,0.5$, and $1 \%)$ on some carcass characteristics and lymphoid organs weight of broiler chicks at the end of the experiment (42 days of age) are presented in Tables (4 and 5). Results showed that, the relative weight of gizzard, bursa of Fabricius and dressing percentage were not statistically $(\mathrm{P}>0.05)$ influenced by the dietary treatments. However, the inclusion of turmeric powder up to $0.25 \%$ in broiler diet cause a significant $(\mathrm{P} \leq 0.5)$ increasing in relative heart, thymus and spleen weights by $12.77,28.57$ and $42.86 \%$ respectively, compared to control group. In the same trend, birds fed diet supplemented with $0.5 \%$ turmeric powder significant $(\mathrm{P} \leq 0.05)$ had the highly carcass percentage by $5.75 \%$ compared to control. On the other hand, birds fed control diet had the highest relative liver and giblets weight compared to the other groups. These results are compatible with findings of Durrani et al., (2006) and Nouzarian et al., (2011) they reported that, the inclusion of turmeric powder in broiler diets significantly caused a decrease in relative liver weight and increase in relative heart weight, accompanied by no differences in relative gizzard weight in comparison with control group

Table (4): Effect of turmeric supplementation levels on some carcass traits of broiler chicks.

\begin{tabular}{lcccccc}
\hline Turmeric levels \% & \% Carcass & \% Dressing & \% Liver & \%Heart & \%Gizzard & \%Giblets \\
\hline Control (T1) & $72.01^{\mathrm{b}}$ & 77.23 & $2.51^{\mathrm{a}}$ & $0.47^{\mathrm{b}}$ & $2.24^{\mathrm{a}}$ & $5.22^{\mathrm{a}}$ \\
$0.25 \%$ (T2) & $73.39^{\mathrm{ab}}$ & 78.12 & $2.28^{\mathrm{ab}}$ & $0.53^{\mathrm{a}}$ & $1.92^{\mathrm{b}}$ & $4.73^{\mathrm{b}}$ \\
$0.50 \%$ (T3) & $76.15^{\mathrm{a}}$ & 80.72 & $2.24^{\mathrm{ab}}$ & $0.50^{\mathrm{ab}}$ & $1.83^{\mathrm{b}}$ & $4.58^{\mathrm{b}}$ \\
$1.00 \%$ (T4) & $72.68^{\mathrm{ab}}$ & 77.20 & $2.14^{\mathrm{b}}$ & $0.49^{\mathrm{ab}}$ & $1.89^{\mathrm{b}}$ & $4.52^{\mathrm{b}}$ \\
SEM & \pm 1.16 & \pm 1.19 & \pm 0.08 & \pm 0.02 & \pm 0.09 & \pm 0.12 \\
Significant & $*$ & NS & $*$ & $*$ & NS & $*$
\end{tabular}

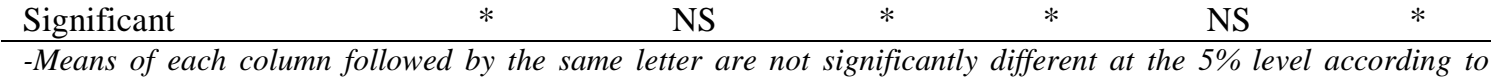
Duncan's Multiple Range Test. SEM indicate standard error of means
NS indicate not significant.

Table (5): Effect of turmeric supplementation levels on lymphoid organs weight of broiler chicks.

\begin{tabular}{lccc}
\hline Turmeric levels \% & \% Thymus & \%Bursa & $\%$ Spleen \\
\hline Control (T1) & $0.28^{\mathrm{b}}$ & 0.06 & $0.07^{\mathrm{b}}$ \\
$0.25 \%$ (T2) & $0.36^{\mathrm{a}}$ & 0.07 & $0.10^{\mathrm{a}}$ \\
$0.50 \%$ (T3) & $0.34^{\mathrm{ab}}$ & 0.06 & $0.09^{\mathrm{ab}}$ \\
$1.00 \%$ (T4) & $0.30^{\mathrm{ab}}$ & 0.06 & $0.08^{\mathrm{ab}}$ \\
SEM & \pm 0.02 & \pm 0.01 & \pm 0.01 \\
Significant & $*$ & NS & $*$
\end{tabular}

Significant

*

Means of each column followed by the same letter are not significantly different at the 5\% level according to Duncan's Multiple Range Test. SEM indicate standard error of means $\quad$-NS indicate not significant. * indicate $P<0.05$

The effect of different inclusion levels of turmeric (curcuma longa) on the intestinal microflora of chickens at the end of the experiment (42 days of age) are presented in Table (6) and Fig. (1and 2).

Means of total bacteria and pathogenic bacteria (total coliform, fecal E. coli, Staphylococcus aureus, Salmonella sp., Shigella sp., and Listeria sp.) counts were reduced in all supplemented groups (T2-T4) as compared to control group (T1). However, dietary supplementation of turmeric led to an increase in means of total lactic acid bacteria counts in all treatment groups (T2-T4) as compared to control group (T1). Results also showed that the intestinal microflora gradually increased or decreased with increasing turmeric concentration up till $1 \%$, being (T4) was the best treatment. The high concentration of turmeric $(1 \%)$ increased the count of total lactic acid bacteria from 7.05 to $9.34 \log _{\mathrm{cfug}^{-1}}\left(1.13 \times 10^{8}-2.21 \times 10^{9}\right.$ $\mathrm{cfug}^{-1}$ ) and decreased each of total count, total coliform bacteria, fecal E. coli, S. aureus and Listeria sp. from 12.08:10.09, 7.99:5.51, 6.73:3.26, 6.53:3.30 and $6.94: 2.90 \log \mathrm{cfug}^{-1}$. 
Table (6): Influence of turmeric supplementation levels on microbiological counts (CFU $\left.\mathrm{g}^{-1}\right) \mathrm{of}^{\mathrm{C}}$ broiler chicks.

\begin{tabular}{lcccc}
\hline & \multicolumn{3}{c}{ Turmeric supplementation levels \% } \\
\cline { 2 - 5 } Microbial counts (CFU g-1) & Control (T1) & $0.25 \%(\mathrm{~T} 2)$ & $0.50 \%(\mathrm{~T} 3)$ & $1.00 \%(\mathrm{~T} 4)$ \\
\hline Total bacterial count & $1.20 \times 10^{12}$ & $1.83 \times 10^{11}$ & $1.38 \times 10^{11}$ & $1.24 \times 10^{10}$ \\
Total lactic acid bacteria & $1.13 \times 10^{8}$ & $1.33 \times 10^{8}$ & $1.89 \times 10^{9}$ & $2.21 \times 10^{9}$ \\
Coliform group & $0.98 \times 10^{8}$ & $0.46 \times 10^{7}$ & $0.36 \times 10^{7}$ & $0.32 \times 10^{6}$ \\
Fecal E. coli & $0.54 \times 10^{7}$ & $0.32 \times 10^{6}$ & $0.61 \times 10^{5}$ & $0.18 \times 10^{3}$ \\
Staphylococcus aureus & $0.34 \times 10^{7}$ & $0.45 \times 10^{5}$ & $0.30 \times 10^{5}$ & $0.20 \times 10^{3}$ \\
Salmonella sp. & $1.05 \times 10^{6}$ & $0.56 \times 10^{6}$ & $0.68 \times 10^{3}$ & 0.00 \\
Shigella sp. & $0.94 \times 10^{6}$ & $0.78 \times 10^{5}$ & $0.43 \times 10^{3}$ & 0.00 \\
Listeria sp. & $0.88 \times 10^{7}$ & $0.50 \times 10^{6}$ & $0.18 \times 10^{4}$ & $0.08 \times 10^{3}$ \\
\hline
\end{tabular}

The regression equation between turmeric concentrations and mean counts of tested bacteria is illustrated by Fig. (1). Results indicated that the regression equation in case of lactic acid bacteria was proportional effect being $\mathrm{Y}=0.5027 \mathrm{X}+7.4428$, it might due to the high concentration of turmeric caused in $\log 10$. Whereas, the regression was disproportionate effect for another tested bacteria being $\mathrm{Y}=-$ $0.608 \mathrm{X}+12.664$ of total bacteria, $\mathrm{Y}=-0.754 \mathrm{X}+8.565$ of total coliform group, $\mathrm{Y}=-1.415 \mathrm{X}+8.3573$ of fecal E. coli, $\mathrm{Y}=-1.8979 \mathrm{X}+8.3953$ of Salmonella sp., $\mathrm{Y}=-1.9178 \mathrm{X}+8.4192$ of Shigella sp., $\mathrm{Y}=-$ $1.3568 \mathrm{X}+8.3424$ of Listeria sp. and $\mathrm{Y}=-0.686 \mathrm{X} 7+6.2076$ of Staphylococcus aureus, respectively, it could be a rebutted to turmeric, with high concentration which decrease the bacterial counts in $\log 10$. In case of Salmonella spp. and Shigella spp. counts, it was observed that the mean counts was decreased with increasing turmeric concentration which decreased up to $5.75 \& 4.89 \mathrm{log} \mathrm{cfug}^{-1}(0.56$ $\left.\times 10^{5} \& 0.78 \times 10^{6} \mathrm{cfug}^{-1}\right)$ at $0.25 \%$ of turmeric in T2 group, $3.83 \& 3.63,\left(0.68 \times 10^{3} \& 0.43 \times 10^{4} \mathrm{cfug}^{-1}\right)$ at $0.5 \%$ turmeric in T3 group. While at $1 \%$ concentration of turmeric, both Salmonella spp. and Shigella spp. did not affect any growth on agar plates.

Results in Fig (2) showed the percentage inhibition of pathogenic bacteria at leading with turmeric with different concentrations $(0.25,0.5$ and $1 \%)$. The effect of turmeric concentration were classified into three categories (strong, moderate and weak) according to percent inhibition which ranged from 4$25 \%, 30-50 \%$ and 51-100\%,respectively. Results indicated that feeding with turmeric supplementation at 0.25 and $0.5 \%$ had an effect ranged from low to moderate inhibition of pathogenic bacteria, while the effect of feeding with $1 \%$ turmeric was high inhibition of pathogenic bacteria as the percentage ranged from 51- 100\%. Both Salmonella spp. and Shigella spp. were strongly inhibited at $100 \%$ with $1 \%$ of turmeric concentration as compared to inhibition at $0.25 \%$ (weak inhibition ranged from 4.49 to $18.09 \%$ ) and $0.5 \%$ (moderate inhibition ranged from $36.38-39.20 \%$ ), respectively. Also, addition of $1 \%$ turmeric as feed supplemented led to inhibit both fecal E. coli and Listeria sp. with high inhibition (51.56 and $58.20 \%$ ) and coliform group with moderate inhibition $(31.04 \%)$, respectively. These results are in agreement with Al-Mashhadani, (2015) who observed that turmeric could control and limit the growth and colonization of numerous pathogenic and non-pathogenic species of bacteria in the chicken's gut resulting in balanced gut microbial ecosystem which leads to better feed utilization that reflected on live body weight and weight gain. And that increase lactobacillus increasing lactobacillus count, accordingly, could be used as growth promoter. Lactobacillus count was significantly $(\mathrm{P}<0.05)$ highest for all supplemented groups as compared to the control. Also, Gupata et al . (2015) reported that, the ability of rhizome of $C$. longa extracts to inhibit the growth of tested pathogen is an indication of its broad spectrum antimicrobial potential which may be employed in the management of microbial infections.

\section{Conclusion}

So, it could be concluded that, dietary supplementation of turmeric (Curcuma longa) at 0.5 and $1.0 \%$ gave an enhancement of Lactic acid bacteria as well as a reduction of pathogenic bacteria in the intestine and improve productive performance of broiler chicken. 


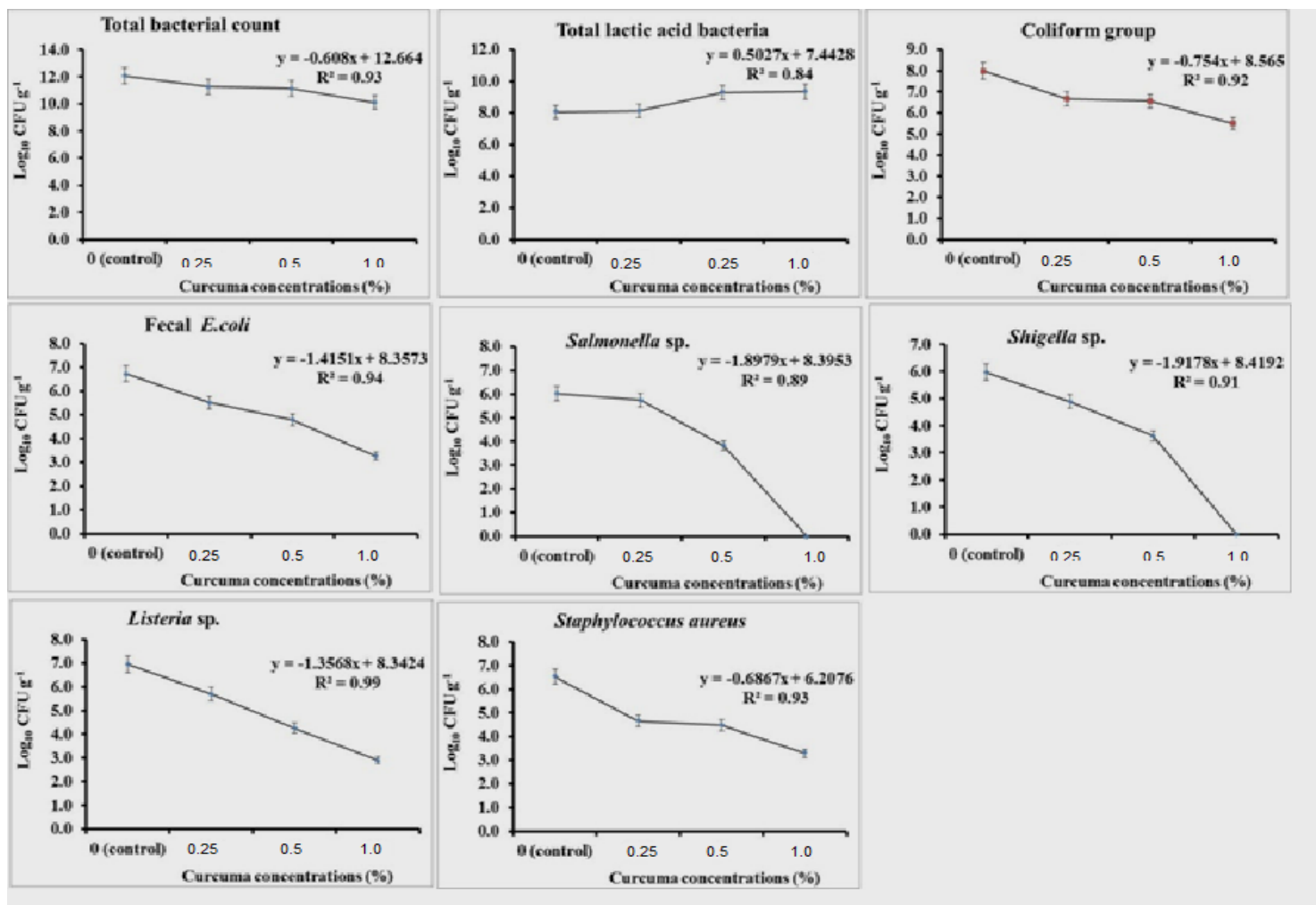

Fig. (1): Regression equation and determination coefficient (R2) between experimental groups and microbial counts in log $10 \mathrm{CFU} \mathrm{g}^{-1}$. Data are expressed as error bars with percentage $5 \%$ value

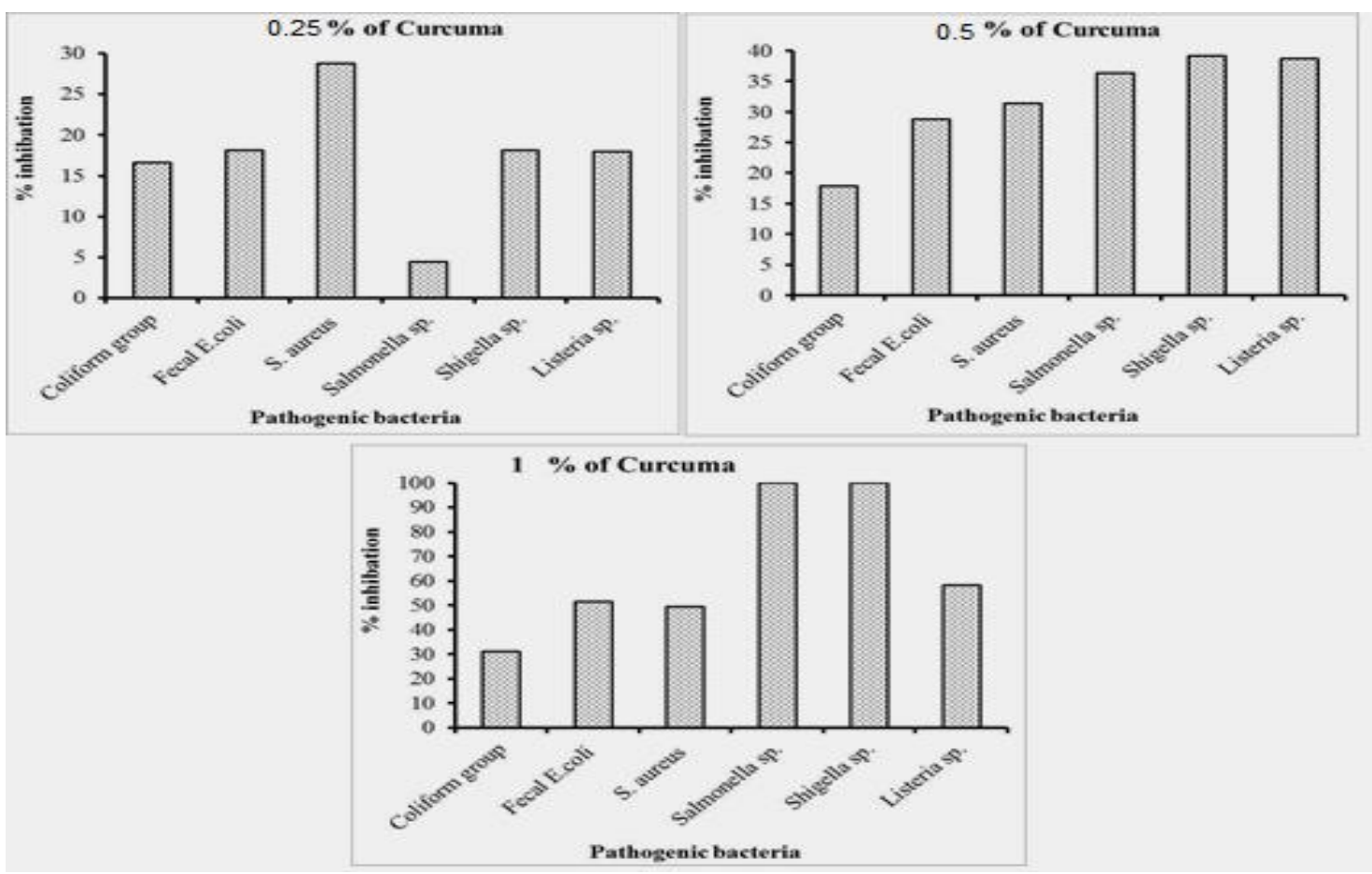

Fig. (2): \% inhibition of pathogenic bacteria using three different concentrations of Curcuma longa $(0.25,0.5$ and $1 \%$ ). 


\section{Ahmed et al.}

\section{REFERENCES}

Al-Mashhadani Hanan E. (2015). Effect of different levels of turmeric (curcuma longa ) supplementation on broiler performance, carcass characteristic and bacterial count. Egypt. Poult. Sci., 35 (I): 25 -39 (2015)

Al-Sultan, S.I, (2003). The effect of Curcuma longa (turmeric) on overall performance of broiler chickens. Int. J. Poult. Sci., 2: 351-353.

Anwarul H.G., J.Abdul, N.Muhammad and M. Kashif.(2006). Pharmacological basis for the use of turmeric in gastrointestinal and respiratory disorders. Life Sci. 76:3089-3105.

Barton, M.D. (1998). Does the use of antibiotics in animals affect human health? Australian Veterinary Journal 76, 177-180.

Bedford, M. (2000). Removal of antibiotic growth promoters from poultry diets: implications and strategies to minimise subsequent problems. World's Poultry Science Journal 56, 347-365.

Chaturvedi T. P.(2009). Uses of turmeric in dentistry: An update. Indian J Dent Res.,20: 107-9.

Duncan, D.B., (1955). Multiple range test and F-test. Biometrics, 11: 1-42.

Durrani F.R, M. Ismail, A. Sultan, S.M. Suhail, N. Chand and Z. Durrani.(2006). Effect of different levels of feed added turmeric (Curcuma longa) on the performance of broiler chicks. J.Agric. Biol. Sci. 1:9-11.

Duvoix, A., R. Blasius, S. Delhalle, M. Schnekenburger, and F. Morceau, (2005). Chemopreventive and therapeutic effects of curcumin. Cancer Letters, 223:181-190.

Eaton, A., L. Clescceri and A. Greenberg, (ed.) (1995) Standard Methods for the Examination of Water and Wastewater. Washington, DC: American Public Health Association.

Farag S. A. and T.K. El-Rayes, (2016). Effect of Bee-pollen supplementation on performance, carcass traits and blood parameters of broiler chickens. Asian J. Anim. Vet. Adv., 11 (3): 168-177.

Gupata A., S. Mahajan and R. Sharma (2015). Evaluation of antimicrobial activity of Curcuma longa rhizome extract against Staphylococcus aureus. Biotechnology Reports 6: 51-55.

Holt, P.R., S. Katz, and R. Kirshoff, (2005). Curcumin therapy in inflammatory bowel disease: a pilot study. Digestive Diseases Science, 50:2191-2193.

Iqbal , M., S.D.Sharma, Y.Okazaki, M. Fujisawa and S. Okada. (2003). Dietary supplementation of curcumin enhance antioxidant and phase II metabolizing enzymes in ddY male mice: possible role in protection against chemical carcinogenesis and toxicity. Pharmacol.Toxicol,92:33-38.

ISO 4833 (2003). Microbiology of food and animal feeding stuffs -- Horizontal method for the enumeration of microorganisms-Colony-count technique at 30 degrees $\mathrm{C}$. published at https://www.sis.se/api/document/preview/916561/

ISO 6579 (2002). Microbiology of food and animal feeding stuffs -- Horizontal method for the detection of Salmonella spp. Published at https://www.salmonella360.com/cms3/assets/fullsize/955

Kang-Ju Kim, Hyeon-Hee Yu and Se-Jeong Seo (2005). Antibacterial activity of curcuma longa L. against Methicillin-resistant Staphylococcus aureus. Phytotherapy Res., 9(7): 599-604.

Niamsa, N. and C. Sittiwet (2009). Antimicrobial activity of curcuma longa aqueous extract. J of Pharmacology and Toxic., 4(4):173-77.

Nouzarian R, S.A Tabeidian, M. Toghyain, G. Ghalamkaei and M. Toghyani 2011. Effect of turmeric powder on performance, carcass traits, humoral immune responses, and serum metabolism in broiler chickens. J.A. and F. Sci, 20: 389-400.

NRC. (1994). National research Council, Nutrient Requirements of poultry. 9th Revealed Edition, Nat. Acad. Press, Washington, DC.USA. 
Osawa, T., Y. Sugiyama, M. Inayoshi and S. Kawakishi, (1995). Antioxidative activity of lower tetrahydrocurcuminoids. Biosci. Biotec. Biochem., 59:1609-12.

Park B.S., M.R. Kim and S.E. Lee ( 2005). Curcuma longa L. constituents inhibit sortase A and Staphylococcus aureus cell adhesion to fibronectin. J Agric., Food Chem., 16; 53(23): 9005-9.

Patterson, J.A., K.M. Burkholder, (2003) Application of prebiotics and probiotics in poultry production. Poult Sci. 82: 627-631.

Platel K. and K. Srinivasan (2000). Influence of dietary spices or their active principles on pancreatic digestive enzymes in albino rats. Food / Nahrung, 44(1):42-46.

Rajput, N., N. Muhammad., R. Yan, X. Zhong, and T. Wang. (2012). Effect of dietary supplementation of curcumin on growth performance, intestinal morphology and nutrients utilization of broiler chicks. J. Poult. Sci. 50: 44-52.

Rambir S., C. Ramesh, B. Mridula (2002). Antibacterial activity of Curcuma longa rhizome extract on pathogenic bacteria. Current Science Sept 2002; 83(6): 737-40.

Soni, K.B., A. Rajan, and R. Kuttan, (1997). Reversal of aflatoxin induced liver damage by turmeric and curcumin. Cancer Letters, 66:115-121.

SPSS Inc (2010). Released 2009. PASW Statistics for Windows, Version 18.0. Chicago: SPSS Inc.

Stephen Cohen and Kenneth Hargreaves (2007). Pathways of the pulp 9th ed. (Mosby publishers, St Louis) 318-19

Toghyani, M., M. Toghyani, A.A. Gheisari, G. Ghalamkari, and M. Mohammadrezaei (2010). Growth performance, serum biochemistry and blood hematology of broiler chicks fed different levels of black seed (Nigella sativa) and peppermint (Mentha piperita). Livestock Science, 129: 173-178.

Toghyani, M., M. Toghyani, A.A. Gheisari, G. Ghalamkari, and S. Eghbalsaeid (2011). Evaluation of cinnamon and garlic as antibiotic growth promoter substitutions on performance, immune responses, serum biochemical and haematological parameters in broiler chicks. Livestock Science, 138:167173.

Wenk, C. (2003). Herbs and botanicals as feed additives in monogastric animals Asian-Australas J Anim Sci, 16 (2003), pp. 282-289.

Whitehead, C.C. (2002). Nutrition and poultry welfare. World's Poultry Science Journal 58, 349-356.

Wuthi-Udomlert, M., W.Grisanapan, O. Luanratana, and W. Caichompoo, (2000). Antifungal activity of Curcuma longa grown in Thailand. Southeast Asian Journal of Tropical Medicine Public Health, $31: 178-182$. 


\title{
تقيميم الإضافة العلفية من الكركم كداعمات نمو نباتية على الأداء الانتاجى والعدد الميكروبى لاجاج التسمين
}

\author{
إيناس أحمد1' و طلعت الريس² و الشيماء أحمد3

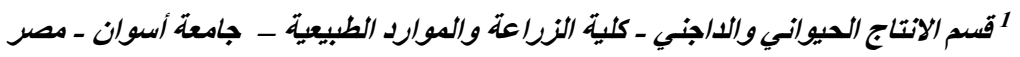

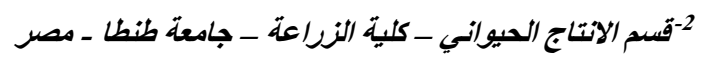

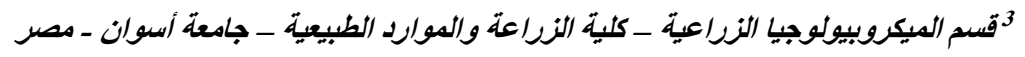

أجريت هذه الدراسة التقييم تأثير الدستويات المختلفة من الكركم علي الأداء الإنتاجي و العدد الميكروبي لاجاج التسمين. أستخدم لهذه

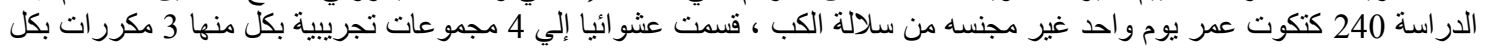

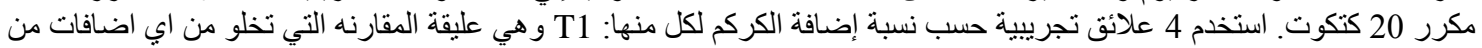

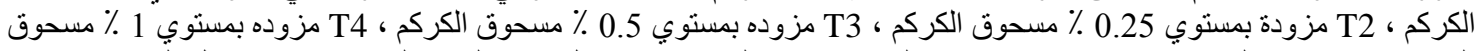

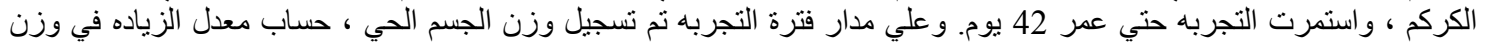
الجسم ، معدل استهلاك العلف ، الكفاءة التحويلية ، خصائص الذبيحه ، العدد الميكروبي.

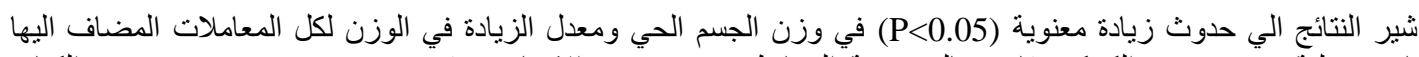

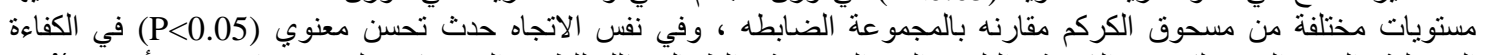

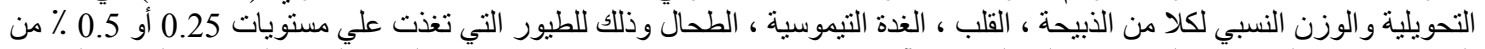

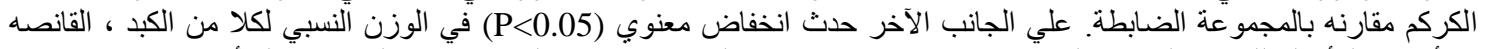

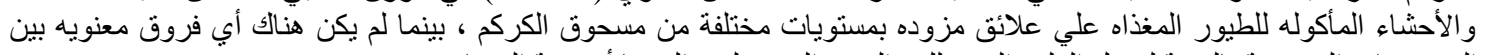

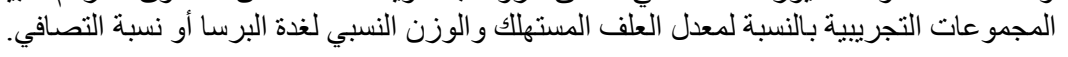

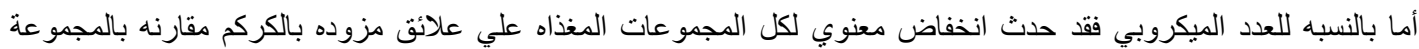

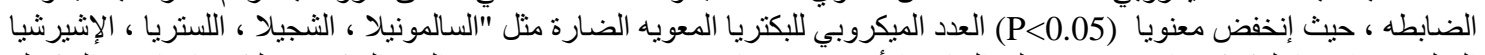

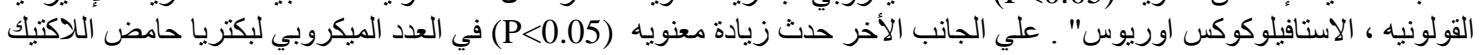

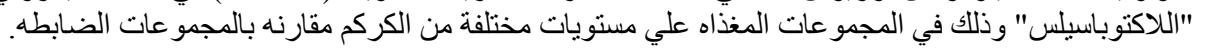

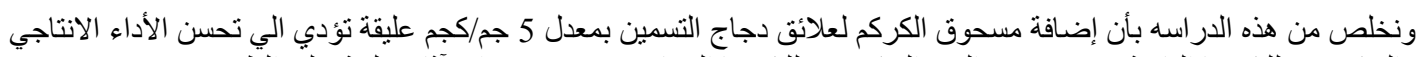

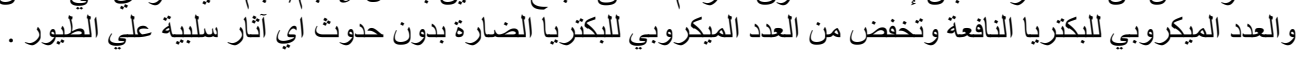

